\title{
CAN COMPLETE BLOOD CELL COUNT PARAMETERS PREDICT DEEP VEIN THROMBOSIS?
}

\author{
Kevser Tural ${ }^{1}$, Fatih $\mathrm{Kara}^{2}$, Sema Avc1 ${ }^{3}$ and Halil İbrahim Erdoğdu ${ }^{4}$ \\ ${ }^{1}$ Kafkas University, Medical Faculty, Department of Cardiovascular Surgery, Kars, Turkey; \\ ${ }^{2}$ Kafkas University, Medical Faculty, Department of Biochemistry, Kars, Turkey; \\ ${ }^{3}$ Amasya University, Medical Faculty, Department of Emergency Medicine, Amasya, Turkey; \\ ${ }^{4}$ Kafkas University, Medical Faculty, Department of Internal Medicine, Kars, Turkey
}

\begin{abstract}
SUMMARY - The aim of this study was to evaluate complete blood cell count parameters including red blood cell indices, white blood cell subtypes, and platelet indices for predicting deep vein thrombosis (DVT). A total of 71 (44 male and 27 female) patients with acute femoral and popliteal DVT diagnosed by doppler ultrasonography during a period of seven years (2011-2017) were included in the study. By matching age and gender, 142 (88 male and 54 female) subjects diagnosed with venous insufficiency in the same time interval were assigned as control group. Data were obtained by reviewing hospital records of the study participants, including clinical and demographic characteristics and complete blood cell parameters. Frequencies of hypertension, diabetes mellitus, chronic obstructive pulmonary disease, chronic renal failure, and coronary arterial disease were higher in DVT group as compared to non-DVT group $(\mathrm{p}<0.05)$. Hemoglobin and lymphocyte values were lower, and red blood cell distribution width, neutrophil, neutrophil to lymphocyte ratio, and platelet to lymphocyte ratio higher in DVT group as compared with non-DVT group $(\mathrm{p}<0.05)$. There was no significant between-group difference in terms of mean corpuscular volume, platelet, mean platelet volume, mean platelet volume to platelet ratio, and platelet distribution width ( $p>0.05$ ). Hypertension, hemoglobin, neutrophil to lymphocyte ratio, and platelet to lymphocyte ratio were independent risk factors for DVT. We found that hypertension, anemia, neutrophil to lymphocyte ratio, and platelet to lymphocyte ratio were independent risk factors for DVT. In particular, neutrophil to lymphocyte ratio and hemoglobin may be used as novel, inexpensive, and reliable diagnostic tools for DVT.
\end{abstract}

Key words: Hypertension; Anemia; Platelet to lymphocyte ratio; Neutrophil to lymphocyte ratio; Deep venous thrombosis

\section{Introduction}

Deep vein thrombosis (DVT) is a cardiovascular disease that occurs when a blood clot forms in deep veins, usually in legs ${ }^{1}$. DVT has an incidence of approximately 1.6:1000 per year' ${ }^{2}$. There are three main risk factors for DVT, i.e. hypercoagulability, venous stasis, and vascular injury ${ }^{3}$. Fine-tuning between procoagulant and anticoagulant factors is indispensable to

Correspondence to: Kevser Tural, MD, Kafkas University, Medical Faculty, Department of Cardiovascular Surgery, Kars, Turkey E-mail: ktr12011@hotmail.com

Received August 30, 2018, accepted October 19, 2018 prevent clotting of blood in vessels ${ }^{3}$. Venous stasis associated with prolonged seated immobility, such as long-distance travels, computer usage, or medical immobility including bed-rest and wheelchair usage is another important risk factor for $\mathrm{DVT}^{4,5}$. A variety of vascular injuries including extremity trauma related to repetitive motion or high-speed collisions are among causes of $\mathrm{DVT}^{6,7}$.

Recently, complete blood cell count (CBC) parameters as inexpensive and practical laboratory tests have become an interesting research area because of their potential benefits with regard to screening, prediction, classification, prognosis, and treatment monitoring of cardiovascular diseases $^{8-11}$. 
Table 1.Demographic and laboratory data of patients with and without DVT

\begin{tabular}{|l|l|l|l|}
\hline & $\begin{array}{l}\text { DVT }(+) \\
(\mathrm{n}=71)\end{array}$ & $\begin{array}{l}\text { DVT }(-) \\
(\mathrm{n}=142)\end{array}$ & p value \\
\hline Age (yrs) & $55.14 \pm 17.42$ & $54.19 \pm 15.64$ & 0.0698 \\
\hline $\begin{array}{l}\text { Gender: } \\
\text { female, } \mathrm{n}(\%) \\
\text { male, } \mathrm{n}(\%)\end{array}$ & $\begin{array}{l}54(38.0) \\
44(62.0)\end{array}$ & $\begin{array}{l}54(38.0) \\
88(62.0)\end{array}$ & $\begin{array}{l}1.000 \\
1.000\end{array}$ \\
\hline Hypertension, $\mathrm{n}(\%)$ & $21(29.6)$ & $5(3.5)$ & 0.000 \\
\hline Diabetes mellitus, $\mathrm{n}(\%)$ & $7(9.9)$ & $1(0.7)$ & $\mathbf{0 . 0 0 1}$ \\
\hline COPD, $\mathrm{n}(\%)$ & $8(11.3)$ & $1(0.7)$ & $\mathbf{0 . 0 0 0}$ \\
\hline SVD, $\mathrm{n}(\%)$ & $2(2.8)$ & $0(0.0)$ & 0.133 \\
\hline CRF, $\mathrm{n}(\%)$ & $6(8.5)$ & $0(0.0)$ & 0.000 \\
\hline CAD,n (\%) & $4(5.6)$ & $1(0.7)$ & $\mathbf{0 . 0 2 5}$ \\
\hline Hb (g/dL) & $12.89 \pm 2.13$ & $14.80 \pm 1.34$ & $\mathbf{0 . 0 0 0}$ \\
\hline MCV(fL) & $83.5 \pm 7.81$ & $85.60 \pm 5.94$ & 0.087 \\
\hline RDW (\%) & $14.00 \pm 4.60$ & $11.77 \pm 5.00$ & 0.006 \\
\hline Neutrophil (10 $/ \mathrm{L})$ & $5.72 \pm 2.31$ & $3.88 \pm 1.09$ & $\mathbf{0 . 0 0 0}$ \\
\hline Lymphocyte (10\%/L) & $1.71 \pm 0.59$ & $1.71 \pm 0.59$ & $\mathbf{0 . 0 0 0}$ \\
\hline NLR & $3.99 \pm 3.24$ & $1.92 \pm 0.73$ & $\mathbf{0 . 0 0 0}$ \\
\hline Plt $\left(10^{9} / \mathrm{L}\right)$ & $240.71 \pm 9.07$ & $243.08 \pm 69.60$ & 0.850 \\
\hline $\begin{array}{l}\text { PLR median } \\
(\% 25-75 \text { percentile) }\end{array}$ & $133.42(98.33-187.53)$ & $110.19(89.80-144.00)$ & $\mathbf{0 . 0 1 0}$ \\
\hline MPV(fL) & $9.78 \pm 1.77$ & $9.79 \pm 1.43$ & 0.952 \\
\hline MPV/platelet (fL) & $0.05 \pm 0.02$ & $0.04 \pm 0.01$ & 0.313 \\
\hline PDW(fL) & $12.70 \pm 2.88$ & $13.19 \pm 2.69$ & 0.295 \\
\hline
\end{tabular}

DVT = deep vein thrombosis; $\mathrm{DM}=$ diabetes mellitus; $\mathrm{HT}=$ hypertension; $\mathrm{COPD}=$ chronic obstructive pulmonary disease; $\mathrm{SVD}=$ cerebrovascular disease $\mathrm{CRF}=$ chronic renal failure; $\mathrm{CAD}=$ coronary artery disease $\mathrm{Hb}=$ hemoglobin; $\mathrm{MCV}=$ mean corpuscular volume; RDW = red cell distribution width; NLR = neutrophil to lymphocyte ratio; $\mathrm{Plt}=$ platelet $\mathrm{PLR}=$ platelet to lymphocyte ratio $\mathrm{MPV}=$ mean platelet volume; $\mathrm{PDW}=$ platelet distribution width

A great number of patients with DVT can develop post-thrombotic syndrome and pulmonary embolism that may cause major health and economic problems, particularly if no early treatment is achieved ${ }^{12,13}$. For this reason, early diagnosis and treatment is essential to prevent the complications of DVT, and in this way to minimize morbidity and mortality and reduce health care costs.

The aim of this study was to evaluate CBC parameters including red blood cell (RBC) indices, white blood cell (WBC) subtypes, and platelet indices for predicting DVT.

\section{Patients and Methods}

This study was approved by the Ethics Committee of our Faculty of Medicine. A total of 71 (44 male and 27 female) patients with acute femoral and popliteal
DVT diagnosed by doppler ultrasonography during a period of seven years (2011-2017) were included in the study. The patients were aged 20-89 years. Exclusion criteria were as follows: active cancer, surgical operation within two months, acute trauma, immobility, autoimmune diseases, and pregnancy. By matching age and gender, 142 (88 male and 54 female) subjects diagnosed with venous insufficiency in the same time interval were assigned as control group. Data were obtained by reviewing hospital records of the participants, including clinical and demographic characteristics and $\mathrm{CBC}$ parameters (hemoglobin levels, hematocrit, mean corpuscular volume (MCV), RBC distribution width (RDW), WBC counts, platelet count, mean platelet volume (MPV), and platelet distribution width (PDW)) measured on an ABX Pentra DX 120 (HORIBA, France) hematology analyzer. Hematologic values in the records were assayed from venous 
Table 2. Univariate and multivariate regression analyses for DVT

\begin{tabular}{|l|l|l|l|l|l|l|}
\hline \multirow{2}{*}{ Variable } & \multicolumn{4}{|l|}{ Univariate analysis } & \multicolumn{3}{l|}{ Multivariate analysis } \\
\cline { 2 - 7 } & Odds ratio & $95 \%$ CI & p value & Odds ratio & $95 \%$ CI & p value \\
\hline $\mathrm{HT}$ & 7.975 & $1.334-47.684$ & 0.023 & 8.005 & $1.417-45.220$ & 0.019 \\
$\mathrm{Hb}$ & 0.462 & $0.310-0.689$ & 0.000 & 0.490 & $0.348-0.692$ & 0.000 \\
$\mathrm{NLR}$ & 4.214 & $2.269-7.827$ & 0.000 & 4.484 & $2.453-8.195$ & 0.000 \\
$\mathrm{PLR}$ & 0.988 & $0.975-1.000$ & 0.048 & 0.987 & $0.975-0.999$ & 0.028 \\
\hline
\end{tabular}

DVT = deep vein thrombosis; $\mathrm{CI}=$ confidence interval; $\mathrm{HT}=$ hypertension; $\mathrm{Hb}=$ hemoglobin; NLR = neutrophil to lymphocyte ratio; PLR = platelet to lymphocyte ratio

blood samples taken simultaneously with the diagnosis of acute DVT. In addition, neutrophil-to-lymphocyte ratio (NLR), platelet-to-lymphocyte ratio (PLR), and MPV-to-platelet ratio were calculated.

The research procedures were performed according to the regulations of the institutional Ethics Committee and the Code of Ethics of the World Medical Association (Declaration of Helsinki).

\section{Statistical analyses}

Data were analyzed by using SPSS software version 20.0 (IBM, USA). In descriptive statistics, continuous variables were expressed as mean \pm standard deviation (SD) and median (0.25-0.75 percentile), and categorical variables as frequency (n) and percentage (\%). The participants were divided into two groups with and without DVT. The normality of distribution was assessed by Kolmogorov-Smirnov test. For numerical variables, differences between patients and controls were tested using Student's t-test for parametric data or Mann-Whitney U test for non-parametric data. Categorical variables were analyzed using Pearson $\chi^{2}$-test and Fisher exact test for parametric and non-parametric data, respectively. To identify the independent predictors of DVT, parameters that were significant in univariate analysis were included in multivariate logistic regression analysis.

Receiver operating characteristic (ROC) curve analysis was used to identify the optimal cut-off values and to compare predictive values for diagnosis of DVT of parameters that were significant in multivariate analysis. The significance of difference between the areas under ROC curves (AUCs) was tested by using the method of DeLong et al. ${ }^{14}$ to compare performances of predictors of DVT. The level of statistical significance was set at $\mathrm{p}<0.05$.

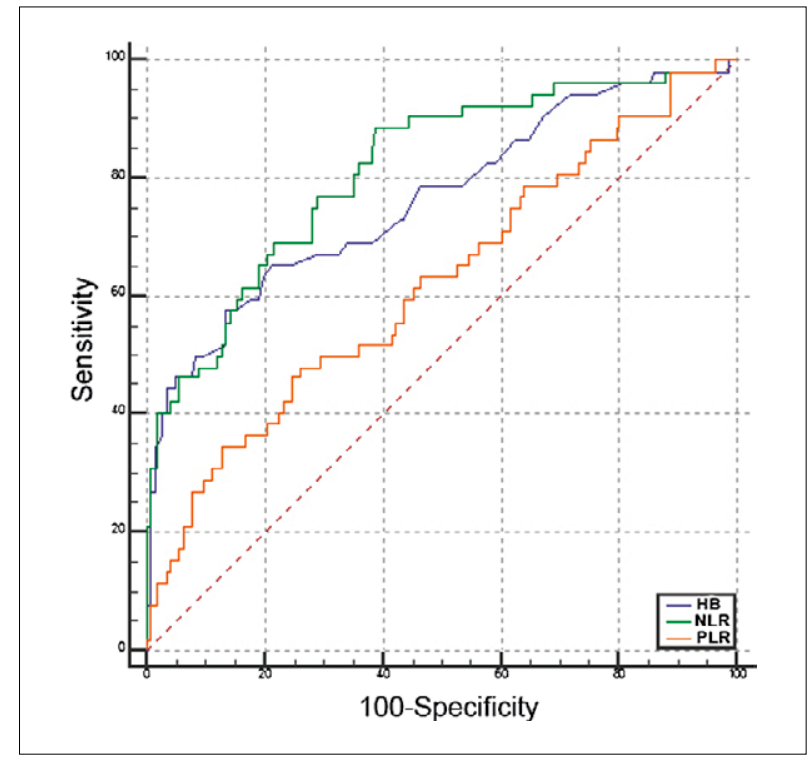

Fig. 1. Comparison of areas under ROC curves (AUCs) for hemoglobin $(\mathrm{Hb})$, neutrophil to lymphocyte ratio (NLR), and platelet to lymphocyte ratio (PLR) in predicting deep vein thrombosis.

\section{Results}

Demographic and laboratory data of patients with and without DVT are shown in Table 1. There was no difference between the groups in age and gender distribution $(p>0.05)$. The frequencies of hypertension (HT), diabetes mellitus (DM), chronic obstructive pulmonary disease (COPD), chronic renal failure $(\mathrm{CRF})$, and coronary arterial disease (CAD) were higher in DVT group as compared with non-DVT group $(\mathrm{p}<0.05)$. Hemoglobin $(\mathrm{Hb})$ and lymphocyte values were lower, and RDW, neutrophil, NLR and PLR higher in DVT group as compared with nonDVT group $(p<0.05)$. There was no significant be- 
tween-group difference according to $\mathrm{MCV}$, PLT, MPV, MPV:platelet ratio, and PDW ( $>0.05)$.

Demographic and laboratory parameters (HT, DM, COPD, CRF, CAD, Hb, RDW, neutrophil count, lymphocyte count, NLR, and PLR) found to be significant in univariate analysis were then included in multivariate analysis. HT, Hb, NLR, and PLR were identified as independent risk factors for DVT. Results of univariate and multivariate analyses are depicted in Table 2.

Additionally, statistical comparisons were made for the AUCs of the parameters found to be independent predictors for DVT in multivariate analysis (Fig. 1). The AUCs for NLR, PLR, and Hb were 0.814 (95\% CI: $0.744-0.884, \mathrm{p}<0.001$ ), 0.621 (95\% CI: $0.529-$ $0.714, \mathrm{p}=0.028$ ), and 0.765 (95\% CI: 0.683-0.848, $\mathrm{p}<0.001)$, respectively. AUC values of NLR and $\mathrm{Hb}$ were similar to each other $(\mathrm{p}=0.3875)$ and higher than that of PLR ( $\mathrm{p}=0.0002$ and $\mathrm{p}=0.0074$, respectively). The sensitivity and specificity for NLR of $>1.9657$ were $88.5 \%$ and $60.6 \%$; for PLR of $>170.539334 .6 \%$ and $87.3 \%$; and for $\mathrm{Hb}$ of $<13.3 \mathrm{~g} / \mathrm{dL} 57.69 \%$ and $86.62 \%$, respectively.

\section{Discussion}

In our study, hypertension was observed in $29.6 \%$ of DVT patients and was found to be an independent risk factor for DVT. In a comprehensive study including 5063 patients with DVT, Sun et al..$^{15}$ report that $55.56 \%$ of patients had hypertension. Similarly, Li et al. ${ }^{16}$ and Guo et al. ${ }^{17}$ found the frequency of hypertension in patients with DVT to be $51.9 \%(27 / 52)$ and $50.8 \%(31 / 61)$, respectively. However, there are a few studies that declare that there is no significant correlation of hypertension with DVT ${ }^{18,19}$. Also, in the study by Ren et al. ${ }^{20}$, hypertension was not a risk factor for DVT relapse. It is well known that hypertension may lead to vascular endothelium dysfunction and hypercoagulable state, and is one of the major risk factors for cardiovascular diseases ${ }^{21-23}$. Our results agree with the majority of studies on the association between DVT and hypertension, and may be interpreted as showing that hypertension made these individuals more susceptible to coagulation.

We found that anemia was an independent risk factor for DVT, which is compatible with previous studies suggesting that anemia is associated with DVT and other cardiovascular disorders ${ }^{24,25}$. This finding may be explained by two scenarios, i.e. underlying common etiologic causes related to both anemia and DVT, and adverse effects related to anemia, such as endothelial dysfunction, hypercoagulable state, and blood stasis ${ }^{24}$. There was a limitation to our study because anemia was not classified. Another study may be designed to determine association between DVT and factors leading to anemia.

It has been demonstrated that there is close association between inflammation and thrombosis ${ }^{26-28}$. Inflammation shows thrombotic effect by stimulating procoagulant factors and platelet reactivity and by inhibiting anticoagulants and fibrinolytic activity ${ }^{26,29}$. Extracellular chromatin originating from neutrophils has been reported to be prothrombotic ${ }^{30}$. These findings may explain why we found NLR as an independent risk factor for DVT. In a previous study, it was suggested that NLR may be useful in determining the extent of venous thromboembolism ${ }^{31}$. However, Roumen-Klappe et $_{\text {al. }}{ }^{32}$ asserted that increased inflammatory markers in DVT might be a result rather than a cause of the disease.

It has been established that PLR is associated with arterial thrombosis and various cancers; however, its role in DVT has not been fully elucidated ${ }^{33,34}$. In our study, PLR was higher in patients with DVT compared to controls. Increased PLR, high platelet counts relative to lymphocyte counts, may indicate elevated predisposition to clot formation ${ }^{33}$. Recently, Mouabbi et al. ${ }^{35}$ have put forward that PLR is superior to D-dimer, increasing classically in clot situations, in terms of predicting the absence or presence of DVT. In the study by Ming et $a l .{ }^{9}$, although it was found that PLR had diagnostic value in unprovoked DVT, it was not an independent risk factor for DVT. In another study, increased PLR was not associated with the risk of venous thromboembolism or cerebral vein thrombosis, but it was associated with thrombophilia abnormalities in cerebral vein thrombosis ${ }^{36}$. However, in our study, since we excluded patients with thrombophilia abnormalities, we may say that elevated PLR could have a predictive value in DVT independent of thrombophilia abnormalities.

In conclusion, we found that HT, anemia, NLR, and PLR were independent risk factors for DVT. Especially NLR and Hb may be used as novel, inexpensive, and reliable diagnostic tools for DVT. Nonetheless, these findings must be supported by further studies. 


\section{References}

1. Budnik I, Brill A. Immune factors in deep vein thrombosis initiation. Trends Immunol. 2018;39(8):610-23.https://doi.org/ 10.1016/j.it.2018.04.010

2. Stubbs MJ, Mouyis M, Thomas M. Deep vein thrombosis. BMJ. 2018;360:k351.https://doi.org/10.1136/bmj.k351

3. Stone J, Hangge P, Albadawi H, Wallace A, Shamoun F, Knuttien MG, et al. Deep vein thrombosis: pathogenesis, diagnosis, and medical management. Cardiovasc Diagn Ther. 2017;7(3): 276-84.https://doi.org/10.21037/cdt.2017.09.01

4. Braithwaite I, Healy B, Cameron L, Weatherall M, Beasley R. Venous thromboembolism risk associated with protracted work- and computer-related seated immobility: a case-control study. JRSM Open. 2016;7(8):2054270416632670.https://doi. org/10.1177/2054270416632670.

5. Pulanić D, Ranković E, Vodanović M, Lušić M, Boban A, Zupančić Šalek S, Nemet D. Extensive deep venous thrombosis in a young male patient as the first manifestation of a rare venous anomaly - inferior vena cava duplication: case report. Acta Clin Croat.2017;56(2):338-43.https://doi.org/10.20471/ acc.2017.56.02.19

6. Echlin PS, Upshur RE, McKeag DB, Jayatilake HP. Traumatic deep vein thrombosis in a soccer player: a case study. Thromb J. 2004;2(1):8.https://doi.org/10.1186/1477-9560-2-8

7. Knudson MM, Ikossi DG. Venous thromboembolism after trauma. Curr Opin Crit Care. 2004;10(6):539-48.https://doi. org/10.1097/01.ccx.0000144941.09650.9f

8. Li N, Zhou H, Tang Q. Red blood cell distribution width: a novel predictive indicator for cardiovascular and cerebrovascular diseases. Dis Markers. 2017;2017:7089493.https://doi.org/ 10.1155/2017/7089493

9. Ming L, Jiang Z, Ma J, Wang Q,Wu F, Ping J. Platelet-to-lymphocyte ratio, neutrophil-to-lymphocyte ratio, and platelet indices in patients with acute deep vein thrombosis. Vasa. 2018;47 (2):143-7.https://doi.org/10.1024/0301-1526/a000683

10. Tajuddin SM, Nalls MA, Zonderman AB, Evans MK. Association of red cell distribution width with all-cause and cardiovascular-specific mortality in African American and white adults: a prospective cohort study.J Transl Med.2017;15(1):208. https://doi.org/10.1186/s12967-017-1313-6

11. Yilmaz M, Dagli MN, Uku O, Bilen MN, Korkmaz H, Erdem $\mathrm{K}$, et al. Focusing on a complete blood cell parameter: mean platelet volume levels may be a predictor of coronary slow flow. Vasc Health Risk Manag. 2017;13:255-61.https://doi.org/ 10.2147/VHRM.S126105

12. Baldwin MJ, Moore HM, Rudarakanchana N, Gohel M, Davies AH. Post-thrombotic syndrome: a clinical review. J Thromb Haemost. 2013;11(5):795-805.https://doi.org/10. 1111/jth.12180

13. Morrone D, Morrone V. Acute pulmonary embolism: focus on the clinical picture. Korean Circ J. 2018;48(5):365-81.https:// doi.org/10.4070/kcj.2017.0314
14. DeLong ER, DeLong DM, Clarke-Pearson DL. Comparing the areas under two or more correlated receiver operating characteristic curves: a nonparametric approach. Biometrics. 1988;44(3):837-45. https://doi.org/10.2307/2531595

15. Sun ML, Wang XH, Huang J, Wang J, Wang Y. Comparative study on deep venous thrombosis onset in hospitalized patients with different underlying diseases. Zhonghua Nei Ke Za Zhi. 2018;57(6):429-34.https://doi.org/10.3760/cma.j.issn.05781426.2018.06.007

16. Li Q, Yu Z, Chen X, Wang J, Jiang G. Risk factors for deep venous thrombosis of lower limbs in postoperative neurosurgical patients. Pak J Med Sci. 2016;32(5):1107-10.https://doi. org/10.12669/pjms.325.10481

17. Guo F, Shashikiran T, Chen X, Yang L, Liu X, Song L. Clinical features and risk factor analysis for lower extremity deep venous thrombosis in Chinese neurosurgical patients. J Neurosci Rural Pract. 2015;6(4):471-6.https://doi.org/10.4103/09763147.169801

18. Song EK, Kim JK, Lee KB, Seon JK. Deep vein thrombosis after total knee replacement: incidence and correlation with clinical risk factors. J Korean Knee Soc. 1998;10(1):18-22.

19. Wang CJ, Wang JW, Chen LM, Chen HS, Yang BY, Cheng SM. Deep vein thrombosis after total knee arthroplasty. J Formos Med Assoc. 2000;99(11):848-53.

20. Ren W, Li Z, Fu Z, Fu Q.Analysis of risk factors for recurrence of deep venous thrombosis in lower extremities. Med Sci Monit. 2014;20:199-204.https://doi.org/10.12659/MSM.889819

21. Lip GY, Li-Saw-Hee FL. Does hypertension confer a hypercoagulable state? J Hypertens. 1998;16(7):913-6.

22. Dong T, Cheng YW, Yang F, Sun PW, Zhu CJ, Zhu L, et al. Chronic stress facilitates the development of deep venous thrombosis. Oxid Med Cell Longev. 2015;2015:384535.https: //doi.org/10.1155/2015/384535

23. Jamwal S, Sharma S. Vascular endothelium dysfunction: a conservative target in metabolic disorders. Inflamm Res. 2018;67 (5):391-405.https://doi.org/10.1007/s00011-018-1129-8

24. Chi G, Gibson CM, Hernandez AF, Hull RD, Kazmi SHA, Younes A, et al. Association of anemia with venous thromboembolism in acutely ill hospitalized patients: an APEX Trial Substudy. Am J Med. 2018;131(8):972.e1-972-e7.https://doi. org/10.1016/j.amjmed.2018.03.031

25. Grammer TB, Kleber ME, Silbernagel G, Pilz S, Scharnagl H, Tomaschitz A, et al. Hemoglobin, iron metabolism and angiographic coronary artery disease (The Ludwigshafen Risk and Cardiovascular Health Study). Atherosclerosis. 2014;236(2): 292-300.https://doi.org/10.1016/j.atherosclerosis.2014.07.002

26. Esmon CT. Inflammation and thrombosis. J Thromb Haemost. 2003;1(7):1343-8. https://doi.org/10.1046/j.1538-7836.2003. 00261.x

27. Poredos P, Jezovnik MK. The role of inflammation in venous thromboembolism and the link between arterial and venous thrombosis. Int Angiol. 2007;26(4):306-11.

28. Rencüzoğulları İ, Karabağ Y, Çağdaş M, Karakoyun S, Yesin M, Artaç İ, et al. ST Segment Yüksekliği Olmayan Miyokard 
İnfarktüsü Hastalarında Nötrofil/Lenfosit Oranı ile SYNTAX ve SYNTAX II Skorları Arasındaki İlişkinin Değerlendirilmesi. Kafkas J Med Sci. 2017;7(2):117-23.https://doi.org/10.5505/ kjms.2017.47587

29. Xu J, Lupu F, Esmon CT. Inflammation, innate immunity and blood coagulation. Hamostaseologie. 2010;30(1):5-6, 8-9.

30. Brill A, Fuchs TA, Savchenko AS, Thomas GM, Martinod K, De Meyer SF, et al. Neutrophil extracellular traps promote deep vein thrombosis in mice. J Thromb Haemost. 2012;10(1):13644.https://doi.org/10.1111/j.1538-7836.2011.04544.x

31. Bakirci EM, Topcu S, Kalkan K, Tanboga IH, Borekci A, Sevimli $\mathrm{S}$, et al. The role of the nonspecific inflammatory markers in determining the anatomic extent of venous thromboembolism. Clin Appl Thromb Hemost. 2015;21(2):181-5.https:// doi.org/10.1177/1076029613494469

32. Roumen-Klappe EM, den Heijer M, van Uum SH, van der Ven-Jongekrijg J, van der Graaf F, Wollersheim H. Inflammatory response in the acute phase of deep vein thrombosis. J Vasc Surg. 2002;35(4):701-6. https://doi.org/10.1067/mva. 2002.121746
33. Hudzik B, Szkodzinski J, Gorol J, Niedziela J, Lekston A, Gasior $\mathrm{M}$, et al. Platelet-to-lymphocyte ratio is a marker of poor prognosis in patients with diabetes mellitus and ST-elevation myocardial infarction. Biomark Med. 2015;9(3):199-207.https: //doi.org/10.2217/bmm.14.100

34. Zhou X, Du Y, Huang Z, Xu J, Qiu T, Wang J, et al. Prognostic value of PLR in various cancers: a meta-analysis. PLoS One. 2014;9(6):e101119.https://doi.org/10.1371/journal.pone.010 1119

35. Mouabbi JA, Szpunar S, Saravolatz L, Kafri Z, Hadid T. Neutrophil-to-lymphocyte ratio and platelet-to-lymphocyte ratio as predictive markers for deep vein thrombosis. Respirology. 2017;22(3):78. https://doi.org/10.1111/resp.13206_186.

36. Artoni A, Abbattista M, Bucciarelli P, Gianniello F, Scalambrino E, Pappalardo E, et al. Platelet to lymphocyte ratio and neutrophil to lymphocyte ratio as risk factors for venous thrombosis. Clin Appl Thromb Hemost. 2018;24(5):808-14. doi: $10.1177 / 1076029617733039$

Sažetak

\section{MOGU LI PARAMETRI KOMPLETNE KRVNE SLIKE PREDVIDJETI DUBOKU VENSKU TROMBOZU?}

\section{K. Tural, F. Kara, S. Avcı i H.I. Erdoğgu}

Cilj ovoga istraživanja bio je procijeniti parametre kompletne krvne slike (KKS) uključujući eritrocitne indekse, podvrste leukocita i trombocitne pokazatelje za predviđanje duboke venske tromboze (DVT). U istraživanje su bila uključena 44 bolesnika i 27 bolesnica, ukupno njih 71, s akutnom femoralnom i poplitealnom DVT dijagnosticiranom Dopplerovom ultrasonografijom tijekom sedam godina (2011.-2017.) i 142 ispitanika (88 muškaraca i 54 žena) izjednačenih po dobi i spolu te s dijagnozom venske insuficijencije postavljenom u istom razdoblju kao kontrolna skupina. Potrebni podaci za sve ispitanike dobiveni su iz njihovih bolničkih zapisa, uključujući kliničke i demografske karakteristike i parametre KKS. Učestalost hipertenzije, šećerne bolesti, kronične opstruktivne plućne bolesti, kroničnog bubrežnog zatajenja i koronarne arterijske bolesti bila je viša u skupini s DVT u usporedbi sa skupinom bez DVT $(p<0,05)$. Vrijednosti hemoglobina i limfoctia bile su niže, a širina distribucije eritrocita, neutrofil, omjer neutrofila i limfocita te omjer trombocita i limfocita bili su viši u skupini s DVT u usporedbi sa skupinom bez DVT $(p<0,05)$. Nije bilo značajne razlike među skupinama u vrijednostima srednjeg korpuskularnog volumena, trombocita, srednjeg volumena trombocita, omjera srednjeg volumena trombocita i širine distribucije trombocita $(p>0,05)$. Hipertenzija, hemoglobin, omjer neutrofila i limfocita te omjer trombocita i limfocita pokazali su se kao neovisni čimbenici rizika za DVT. Utvrdili smo da su hipertenzija, anemija, omjer neutrofila i limfocita te omjer trombocita i limfocita neovisni čimbenici rizika za DVT. Naročito bi se omjer neutrofila i limfocita te hemoglobin mogli rabiti kao novi, jeftini i pouzdani dijagnostički alati za DVT.

Ključne riječi: Hipertenzija; Anemija; Omjer trombocita i limfocita; Omjer neutrofila i limfocita; Duboka venska tromboza 